\section{Trends in non-AIDS-related causes of death among adults with HIV/AIDS, Brazil, 1999 to 2010}

\author{
Tendência de causas não associadas ao HIV/AIDS \\ como causas de óbito entre adultos que viviam \\ com HIV/AIDS no Brasil, 1999 a 2010
Tendencia de las causas no asociadas al VIH/SIDA, como causa de muerte entre adultos que vivían con el VIH/SIDA en Brasil, de 1999 a 2010

\begin{abstract}
${ }^{1}$ Universidade de Brasília, Brasília, Brasil.

2 Faculdade de Medicina de Barbacena, Barbacena Brasil.

Correspondence E. Fazito

Universidade de Brasília. 26 Chemin Colladon, 1209 Geneva, Switzerland. erikafazito@gmail.com
\end{abstract}

\begin{abstract}
The aim of this study was to analyze trends in the listing of non-AIDS-related causes of death on the death certificates of adults with HIVIAIDS in Brazil. The study analyzed mortality data for persons 15 to 69 years of age from 1999 to 2010. Standardized mortality odds ratios were used to compare mortality from non-AIDS-related causes in the group with HIVIAIDS listed on the death certificate and in the group without HIVI AIDS. From 1999 to 2010, there were 6,120,670 deaths among adults in Brazil. Deaths in the HIV group represented $2.2 \%$ of the total. NonAIDS-related causes, and more specifically cardiovascular diseases, diseases of the genitourinary system, and non-AIDS-related malignant neoplasms increased at higher rates in the group with HIVIAIDS listed on the death certificate. The results point to a greater increase in mortality from non-AIDS-related diseases among persons with HIVIAIDS. This finding suggests that long contact with HIV and antiretroviral therapy play an important role in the occurrence of these diseases.
\end{abstract}

Acquired Immunodeficiency Syndrome; HIV; Causes of Death; Death Certificates
Erika Fazito 1

Ana Maria Nogales Vasconcelos 1 Maurício Gomes Pereira 1 Dilermando Fazito de Rezende 2

\section{Resumo}

O objetivo deste estudo foi analisar a tendência de menções a causas não relacionadas ao HIVI AIDS em adultos que viviam com esta doença no Brasil. Foram analisados os dados de óbitos de pessoas de 15 a 69 anos, ocorridos entre 1999 e 2010. Utilizaram-se as razões de chance de mortalidade padronizadas para comparar a mortalidade de causas não associadas ao HIVIAIDS entre o grupo em que havia menção ao HIV/ AIDS na declaração de óbito e o grupo em que não havia. De 1999 a 2010, ocorreram 6.120.670 óbitos entre adultos no país. Os óbitos do grupo HIV representaram 2,2\% do total. Causas não associadas ao HIV, mais especificamente, doenças cardiovasculares, do aparelho genito-urinário e neoplasias malignas não associadas ao HIV apresentaram crescimento maior no grupo em que também havia menção ao HIVIAIDS. Os resultados apontam para um aumento maior da mortalidade por doenças não associadas ao HIV entre pessoas que viviam com HIVIAIDS. Esse resultado sugere que o longo convívio com o HIV e a terapia antirretroviral exercem importante papel na ocorrência desses agravos.

Síndrome de Imunodeficiência Adquirida; HIV; Causas de Morte; Atestado de Óbito 


\section{Introduction}

AIDS mortality indicators in Brazil are monitored by the Ministry of Health through deaths notified to the Mortality Information System (SIM). These indicators are calculated based on the number of deaths with the underlying case coded as HIV/ AIDS (codes B20 to B24 in the International Classification of Diseases, 10th Revision - ICD-10).

According to the Ministry of Health, from 1980 to 2010 there were 241,469 deaths from AIDS in Brazil 1. The AIDS mortality trend in the country increased until 1996, when it reached 9.6/100,000 inhabitants. Starting that year, the mortality rate declined and then stabilized around some 6/100,000 inhabitants.

At the beginning of the AIDS epidemic, the most frequently recorded causes of death on the death certificate (DC) in persons with HIV/AIDS were opportunistic infectious diseases such as: tuberculosis; candidiasis and other mycoses; toxoplasmosis; pneumonia and other diseases of the respiratory system 2; and HIV-related neoplasms.

Since Brazil adopted a policy of universal and free access to antiretroviral drugs in the public healthcare system in 1996, there were changes in the morbidity and mortality profile from AIDS in the country. There was a sharp drop in mortality from AIDS in Brazil, along with an increase in survival, allowing persons infected with HIV to live longer with the virus.

The effects related to the longer co-habitation with the virus and with its co-morbidities along with the adverse effects of antiretroviral therapy made the condition of living with HIV acquire similar characteristics to those of other chronic and degenerative diseases 3 . In addition to the traditional causes, cardiovascular diseases, liver diseases, diabetes mellitus, viral hepatitis, and acute and chronic renal diseases began to be recorded more frequently on death certificates of persons with HIV/AIDS 4 .

Thus, the analysis of AIDS mortality based only on the underlying cause of death presents limitations. The analysis of underlying cause fails to consider other conditions that contribute directly or indirectly to death and that could help understanding the morbidity profile in AIDS mortality in the country.

This study aimed to analyze mortality trends due to causes usually considered unrelated to HIV/AIDS in deaths among adults from 1999 to 2010. The study compared deaths in which HIV/ AIDS was listed on the DC (the HIV group) and deaths with no mention of HIV/AIDS (the nonHIV group). The data were analyzed with the multiple causes of death approach. That is, in ad- dition to the underlying cause of death, defined as the cause that started the chain of events that culminated in death, the study analyzed the related causes, defined as the antecedent causes listed in part I of the death certificate, and the causes that contributed to death but were not directly associated with the underlying cause, listed in part II of the death certificate.

\section{Methods}

This was a descriptive trend study analyzing data on deaths notified to the SIM, with a case-control design.

The study analyzed data on deaths in Brazil among individuals 15-69 years of age from 1999 to 2010 , notified to the SIM. The decision was made to analyze individuals 15-69 years of age for the following reasons: (i) this age bracket includes nearly $100 \%$ of deaths from HIV/AIDS in adults in Brazil and (ii) in individuals 70 years and older the mortality rate from HIV/AIDS decrease considerably when compared to other age groups (unpublished data).

Non-nominal individual data on deaths recorded in the SIM can be accessed on the website of the Information Technology Department of the Unified National Health System (http:// www.datasus.gov.br).

The variables age (15-29, 30-39, 40-49, 5059, and 60-69 years), gender (male or female), group (HIV or non-HIV), year of death (as a continuous and categorical variable), region of residence, race/color (white or other), place of death (health service versus other), and multiple causes of death (underlying and related causes) were accessed during the analysis.

The analysis aimed to compare trends in listed non-AIDS-related causes of death in the HIV group, consisting of death certificates that mentioned HIV/AIDS in any of the sections (codes B20 to B24, F02.4, R75, Z11.4, Z20.6, Z21, and Z71.7 from the ICD-10) 5 and the non-HIV group, consisting of all other deaths.

The study began by describing the deaths that occurred during the period and verifying the factors associated with listing of HIV/AIDS on the DC through logistic regression, with the group (HIV or non-HIV) as the dependent variable and the following independent variables: gender, age, year of death, region of residence, place of death, and race/color.

The study then analyzed the trends in nonAIDS-related causes. Five analyses were performed in which the dependent variables were defined according to the presence or absence of the following on any line in the DC: (i) cardiovas- 
cular diseases (I00 to I99, except I46); (ii) diabetes mellitus (E10 to E14), (iii) diseases of the genitourinary system (N00 to N29); (iv) non-AIDSrelated malignant neoplasms (C00 to C80, except sarcoma of Kaposi and malignant neoplasm of uterine cervix); and (v) the set of non-AIDS-related causes, defined as non-AIDS-related malignant neoplasms (C00 to C80, except sarcoma of Kaposi - C46 and malignant neoplasm of cervix uteri - C53), diabetes mellitus (E10 to E14), cardiovascular diseases (I00 to I99, except I46), diseases of the digestive system (K00 to K93), diseases of the genitourinary system (N00 to N99), and external causes (S00 to Y98).

For each condition, the study described factors associated with its listing on the DC, according to group (HIV versus non-HIV), using logistic regressions in which the dependent variable was the presence or absence of the condition and the independent variables were year of death, gender, age bracket, and region of residence.

Finally, the study compared the time trends for non-AIDS-related diseases between the HIV and non-HIV groups, using the standardized mortality odds ratios (SMOR) 6. This statistic is used to compare mortality between two groups when the data for the denominator are not available to calculate the mortality rate $4,7,8$. To use the SMOR, the mortality data should be analyzed as if they were data from a case-control study. Therefore, the current study was structured as follows: (i) cases were defined as deaths with the target cause mentioned; (ii) controls were defined as deaths with no mention of the target cause; (iii) the exposed were defined as deaths listing HIV/ AIDS on the DC (HIV group); and (iv) the unexposed were defined as those not listing HIV/AIDS on the DC (non-HIV group).

To calculate the SMOR, logistic regression models were adjusted 9 in which the dependent variable was defined as the presence or absence of listing of the target cause of death on the DC. The selected covariables were year of death, gender, age bracket, and region of residence. The difference between the time trends in causes of death between the exposed and unexposed was tested by adding an interaction term to the logistic regression equation, consisting of the year of death and the group (HIV or non-HIV).

The analysis used SPSS 16 for Windows (SPSS Inc., Chicago, USA).

\section{Results}

From 1999 to 2010, there were 6,120,670 deaths among individuals 15-69 years of age in Brazil. The majority occurred in men, in individuals 60-
69 years of age, and in residents of the Southeast region. The HIV group totaled 136,908 deaths, i.e., a mean of 11,400 deaths per year among persons with HIV/AIDS and representing 2.2\% of all deaths in the same period. Deaths in the HIV group as compared to the non-HIV group showed 11.6 times higher odds of occurring in healthcare establishments, $10 \%$ higher odds of occurring in males, $80 \%$ higher odds of occurring in residents of the South as compared to the North of Brazil, and $10 \%$ higher odds of occurring in non-white individuals. Mean age at death was 39 years in the HIV group and 49 years in the nonHIV group (Table 1).

In the HIV group, "non-AIDS-related causes" were listed in $16.6 \%$ of the deaths in 1999 . This proportion increased to $28.9 \%$ in 2010 . In the non-HIV group, this indicator varied from $76.4 \%$ to $83.2 \%$ in the same period. After adjusting for age, gender, and region of residence, the mean annual increase in non-AIDS-related causes in the HIV group was $3.9 \%$ (95\%CI: 3.5-4.3; p < 0.001 ) and $4.3 \%$ in the non-HIV group $(95 \% \mathrm{CI}$ : 4.3-4.4; $\mathrm{p}<0.001)$. The interaction term was significant (SMOR $=1.011 ; 95 \% C I$ : $1.01-1.02$ ) in the model, showing that the trends in the mortality curves for non-AIDS-related causes were different between the two groups $(p=0.001)$ and that the increase was greater in the HIV group.

Among non-AIDS-related causes, cardiovascular diseases showed a greater increase in the HIV group compared to the non-HIV group. Listing of cardiovascular diseases increased from $4.3 \%$ in 1999 to $8.1 \%$ in 2010 , with an adjusted mean increase of $3.8 \%$ per year $(95 \% \mathrm{CI}$ : $3.2-$ $4.5 ; \mathrm{p}<0.001$ ) in the HIV group. In the non-HIV group, an increase of $0.4 \%$ per year was observed (95\%CI: $0.4-0.5 ; \mathrm{p}<0.001)$ and the indicator increased from $33.5 \%$ in 1999 to $35 \%$ in 2010 . The interaction term was significant $(\mathrm{SMOR}=1.020$; 95\%CI: 1.01-1.03) in the model, showing that the trends in mortality curves from cardiovascular diseases were different between the two groups $(p=0.001)$ and that the increase was greater in the HIV group. The odds ratio for listing cardiovascular diseases on the DC in 2010 compared to 1999 was 1.0 (95\%CI: $1.0-1.1)$ for the non-HIV group and 1.7 (95\%CI: 1.5-1.9) for the HIV group (Figure 1).

In the HIV group, diseases of the genitourinary system were listed in $4.2 \%$ of the deaths in 1999, increasing to $9.8 \%$ in 2010 . In the non-HIV group this proportion increased from $5.2 \%$ to $8.7 \%$ in the same period. After adjusting for age, gender, and region of residence, the mean annual increase in diseases of the genitourinary system in the non-HIV group was $4.2 \%$ (95\%CI: 4.1-4.3; $\mathrm{p}<0.001)$ and $5.7 \%$ in the HIV group $(95 \% \mathrm{CI}$ : 
Distribution of characteristics and factors associated with listing of HIV/AIDS on the death certificate in individuals 15-69 years of age in Brazil, 1999-2010, by group.

\begin{tabular}{|c|c|c|c|c|c|c|}
\hline \multirow[t]{3}{*}{ Variables/Categories } & \multicolumn{4}{|c|}{ Group } & \multirow[t]{3}{*}{ Total } & \multirow{3}{*}{$\begin{array}{c}\text { Adjusted OR } \\
(95 \% \mathrm{Cl})\end{array}$} \\
\hline & \multicolumn{2}{|c|}{ Non-HIV/AIDS } & \multicolumn{2}{|c|}{ HIV/AIDS } & & \\
\hline & $\mathrm{n}$ & $\%$ & $\mathrm{n}$ & $\%$ & & \\
\hline \multicolumn{7}{|l|}{ Age bracket (years) } \\
\hline $15-29$ & 855,435 & 97.4 & 23,261 & 2.6 & 878,696 & 1.0 \\
\hline $30-39$ & 677,324 & 93.0 & 50,954 & 7.0 & 728,278 & $2.4(2.4-2.5)$ \\
\hline $40-49$ & $1,033,840$ & 96.3 & 40,013 & 3.7 & $1,073,853$ & $1.1(1.1-1.1)$ \\
\hline $50-59$ & $1,464,614$ & 98.9 & 16,941 & 1.1 & $1,481,555$ & $0.3(0.3-0.3)$ \\
\hline $60-69$ & $1,952,549$ & 99.7 & 5,739 & 0.3 & $1,958,288$ & $0.1(0.1-0.1)$ \\
\hline \multicolumn{7}{|l|}{ Gender } \\
\hline Female & $3,933,659$ & 97.7 & 92,813 & 2.3 & $4,026,472$ & 1.0 \\
\hline Male & $2,050,103$ & 97.9 & 44,095 & 2.1 & $2,094,198$ & $1.1(1.1-1.1)$ \\
\hline \multicolumn{7}{|l|}{ Region of residence } \\
\hline North & 330,029 & 98.0 & 6,664 & 2.0 & 336,693 & 1.0 \\
\hline Northeast & $1,417,323$ & 98.7 & 18,467 & 1.3 & $1,435,790$ & $0.7(0.7-0.7)$ \\
\hline Southeast & $2,891,979$ & 97.4 & 75,709 & 2.6 & $2,967,688$ & $1.3(1.3-1.3)$ \\
\hline South & 941,146 & 97.1 & 28,536 & 2.9 & 969,682 & $1.8(1.8-1.9)$ \\
\hline Central-West & 403,285 & 98.2 & 7,532 & 1.8 & 410,817 & $0.9(0.9-0.9)$ \\
\hline \multicolumn{7}{|l|}{ Year of death } \\
\hline 1999 & 468,670 & 97.9 & 10,236 & 2.1 & 478,906 & 1.0 \\
\hline 2000 & 472,186 & 97.8 & 10,584 & 2.2 & 482,770 & $1.0(1.0-1.0)$ \\
\hline 2001 & 478,038 & 97.8 & 10,806 & 2.2 & 488,844 & $1.0(1.0-1.1)$ \\
\hline 2002 & 485,107 & 97.8 & 10,973 & 2.2 & 496,080 & $1.0(1.0-1.1)$ \\
\hline 2003 & 489,964 & 97.8 & 11,220 & 2.2 & 501,184 & $1.1(1.0-1.1)$ \\
\hline 2004 & 501,015 & 97.9 & 11,006 & 2.1 & 512,021 & $1.0(1.0-1.1)$ \\
\hline 2005 & 491,990 & 97.8 & 11,064 & 2.2 & 503,054 & $1.1(1.1-1.1)$ \\
\hline 2006 & 499,607 & 97.8 & 11,453 & 2.2 & 511,060 & $1.1(1.1-1.1)$ \\
\hline 2007 & 506,312 & 97.7 & 11,790 & 2.3 & 518,102 & $1.1(1.1-1.2)$ \\
\hline 2008 & 521,080 & 97.7 & 12,302 & 2.3 & 533,382 & $1.2(1.1-1.2)$ \\
\hline 2009 & 529,437 & 97.6 & 12,742 & 2.4 & 542,179 & $1.2(1.1-1.2)$ \\
\hline 2010 & 540,356 & 97.7 & 12,732 & 2.3 & 553,088 & $1.2(1.2-1.2)$ \\
\hline \multicolumn{7}{|l|}{ Race/Color } \\
\hline White & $2,903,946$ & 97.7 & 68,995 & 2.3 & $2,972,941$ & 1.0 \\
\hline Other & $2,483,904$ & 97.8 & 56,495 & 2.2 & $2,540,399$ & $1.1(1.0-1.1)$ \\
\hline \multicolumn{7}{|l|}{ Place of death } \\
\hline Other & $1,929,660$ & 99.6 & 7,011 & 0.4 & $1,936,671$ & 1.0 \\
\hline Healthcare establishment & $3,995,040$ & 96.9 & 129,432 & 3.1 & $4,124,472$ & $11.6(11.3-11.9)$ \\
\hline
\end{tabular}

95\%Cl: 95\% confidence interval; OR: odds ratio.

5.0-6.3; $\mathrm{p}<0.001)$. The interaction term was significant $(\mathrm{SMOR}=1.009$; 95\%CI: $1.003-1.015)$ in the model, showing that trends in the mortality curves from diseases of the genitourinary system were different between the two groups $(p=0.005)$ and that the increase was greater in the HIV group. The OR for listing of diseases of the genitourinary system on the DC in 2010 compared to 1999 was 1.7 (95\%CI: 1.7-1.8) in the non-HIV group and
2.3 (95\%CI: 2.0-2.5) in the HIV group (Figure 2). The distribution of diseases of the genitourinary system was similar in the two groups, with some $75 \%$ of the listings due to renal failure (ICD-10: N17 to N19).

In the HIV group, non-AIDS-related malignant neoplasms were listed in $1.7 \%$ of the deaths in 1999 , increasing to $4.1 \%$ in 2010 . In the nonHIV group this indicator increased from $13.7 \%$ to 
Odds ratios and $95 \%$ confidence intervals for deaths in individuals 15-69 years of age listing cardiovascular diseases on the death certificate, by group. Brazil, 1999-2010.

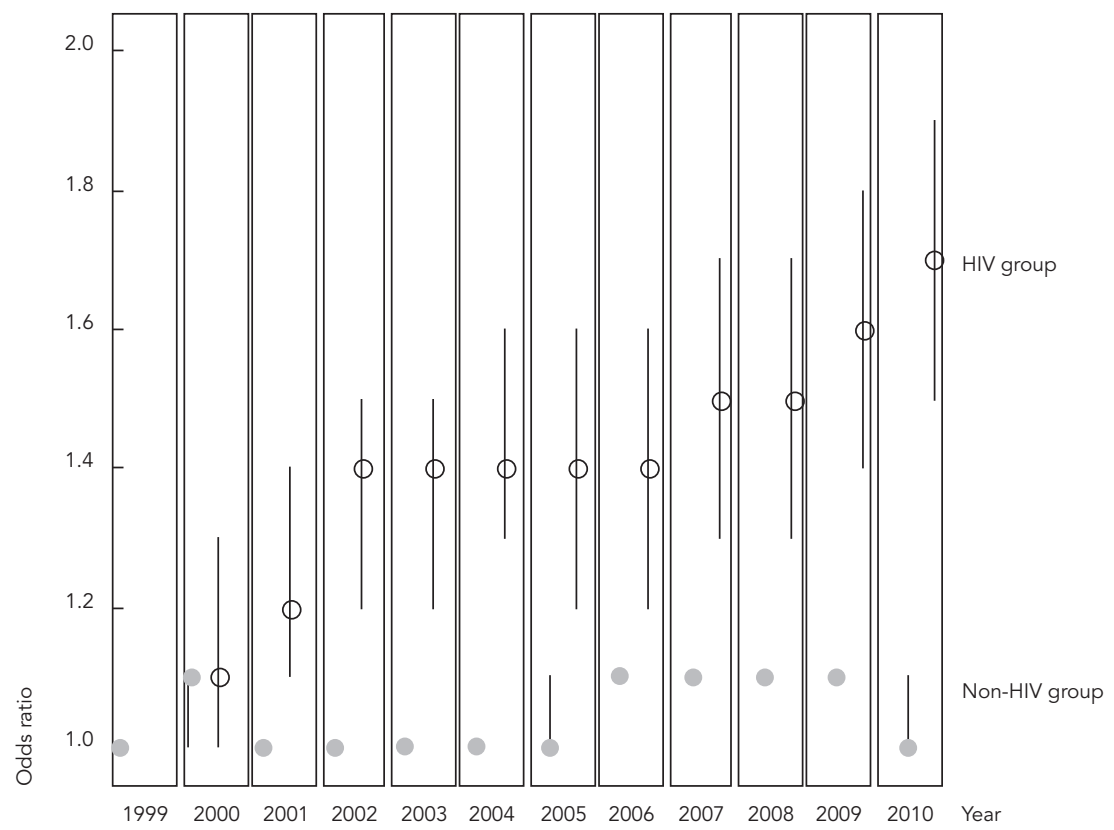

$17.1 \%$ during the same period. After adjusting for age, gender, and region of residence, the mean annual increase in non-AIDS-related neoplasms was $5.0 \%$ in the HIV group (95\%CI: $4.1-6.1 ; \mathrm{p}<$ 0.001 ) and $0.5 \%$ in the non-HIV group (95\%CI: 2.4-2.6; $\mathrm{p}<0.001)$. The interaction term was significant (SMOR $=1.021 ; 95 \%$ CI: $1.01-1.03$ ) in the model, showing that trends in the mortality curves from non-AIDS-related neoplasms were different between the two groups ( $p=0.001$ ) and that the increase was greater in the HIV group. The OR for listing of non-AIDS-related neoplasms on the DC in 2010 compared to 1999 was 1.3 (95\%CI: 1.3-1.3) in the non-HIV group and 2.0 (95\%CI: 1.7-2.4) in the HIV group (Figure 3). The more frequent listings of non-AIDS-related malignant neoplasms in the HIV group, unlike the non-HIV group, were for neoplasms of the bronchi and lungs, brain, and hepatocellular carcinomas.

In the HIV group, diabetes mellitus was listed in $0.6 \%$ of the deaths in 1999, increasing to $1.7 \%$ in 2010. In the non-HIV group this indicator increased from $6.1 \%$ to $8.3 \%$ during the same period. After adjusting for age, gender, and region of residence, the mean annual increase in listing diabetes mellitus was $4.1 \%$ in the HIV group
(95\%CI: 2.6-5.5; $\mathrm{p}<0.001)$ and $2.5 \%$ in the nonHIV group (95\%CI: 2.4-2.6; $\mathrm{p}<0.001$ ). The interaction term was not significant (SMOR $=1.011$; 95\%CI: 0.997-1.025) in the model, i.e., trends in the mortality curves from diabetes mellitus did not differ between the two groups $(p=0.112)$.

\section{Discussion}

The availability of multiple causes of death in the Brazilian mortality data since 1999 provides an important source of information for a better understanding of the mortality pattern among persons who lived with HIV/AIDS in Brazil. Thus, two similar studies have already been published with the aim of assessing the mortality trend from non-AIDS-related causes in the country. The first study found that among all deaths from 1999 to $2004^{4}$, the trend in deaths from non-AIDS-related causes, more specifically from cardiovascular diseases and diabetes mellitus, showed a larger increase in the group that also listed HIV/ AIDS on the death certificate. The second study showed that among deaths in children from 1999 to 2007 10, the trend in deaths from non-AIDS- 
Odds ratios and 95\% confidence intervals for deaths in individuals 15-69 years of age listing diseases of the genitourinary system on the death certificate, by group. Brazil, 1999-2010.

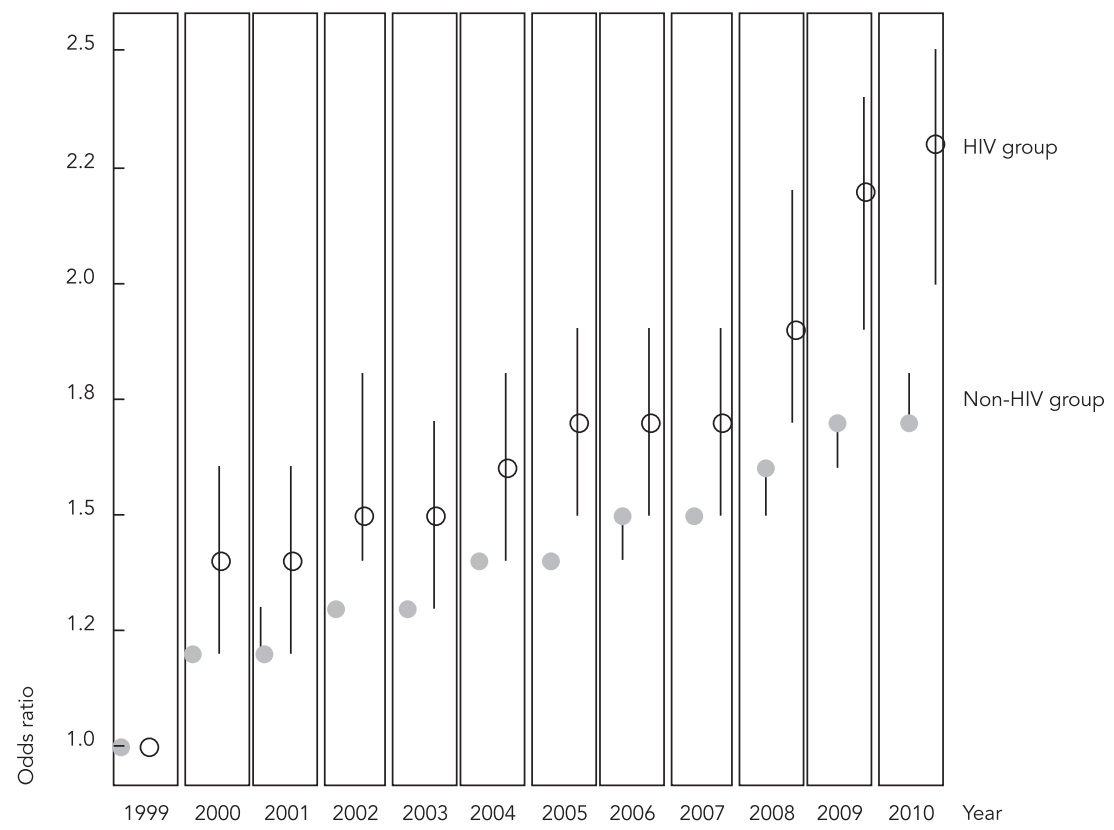

related causes remained stable in the group that listed HIV/AIDS on the death certificate, while the trend in AIDS-related causes decreased.

In order to improve and contribute to knowledge on the mortality profile in persons with HIV/AIDS in Brazil, the current study sought to differentiate itself from the previous studies by analyzing deaths among adults and by assessing the trend in deaths from diseases of the genitourinary system and from non-AIDS-related malignant neoplasms, in addition to trends in nonAIDS-related diseases, diabetes mellitus, and cardiovascular diseases.

The study's results confirm that the mortality pattern among adults with HIV/AIDS has changed since the introduction of highly active antiretroviral therapy (HAART). Compared to 1999, the number of deaths listing non-AIDSrelated causes increased more in the group that listed HIV/AIDS on the death certificate when compared to the group not listing HIV/AIDS. Other authors have reported similar results for some time in developed countries 11,12,13,14,15.

Considering that the increase in mean age at time of death was significantly greater in the HIV group when compared to the non-HIV group (data not published), it is believed that the aging resulting from the increased survival of patients with AIDS is an important factor in the changing mortality pattern of the adult population with HIV. However, it is also believed that HAART and the long contact with HIV are contributing to the increase in deaths from causes not related to HIV/ AIDS among persons with HIV/AIDS, since these causes displayed a significantly higher proportional increase in the HIV group when compared to the non-HIV group during the study period, even after adjusting for age.

The results also suggest that among nonAIDS-related causes, the trend in the mortality curves from cardiovascular diseases is increasing significantly more in the HIV group when compared to the non-HIV group. These results agree with findings by other authors showing an increase in deaths from cardiovascular diseases in persons with HIV/AIDS since the introduction of HAART 13,16,17.

In addition to the high prevalence of risk factors for cardiovascular diseases such as smoking, arterial hypertension, and elevated triglycerides and VHDL cholesterol among persons with HIV/ AIDS 18, studies suggest that HAART and the 


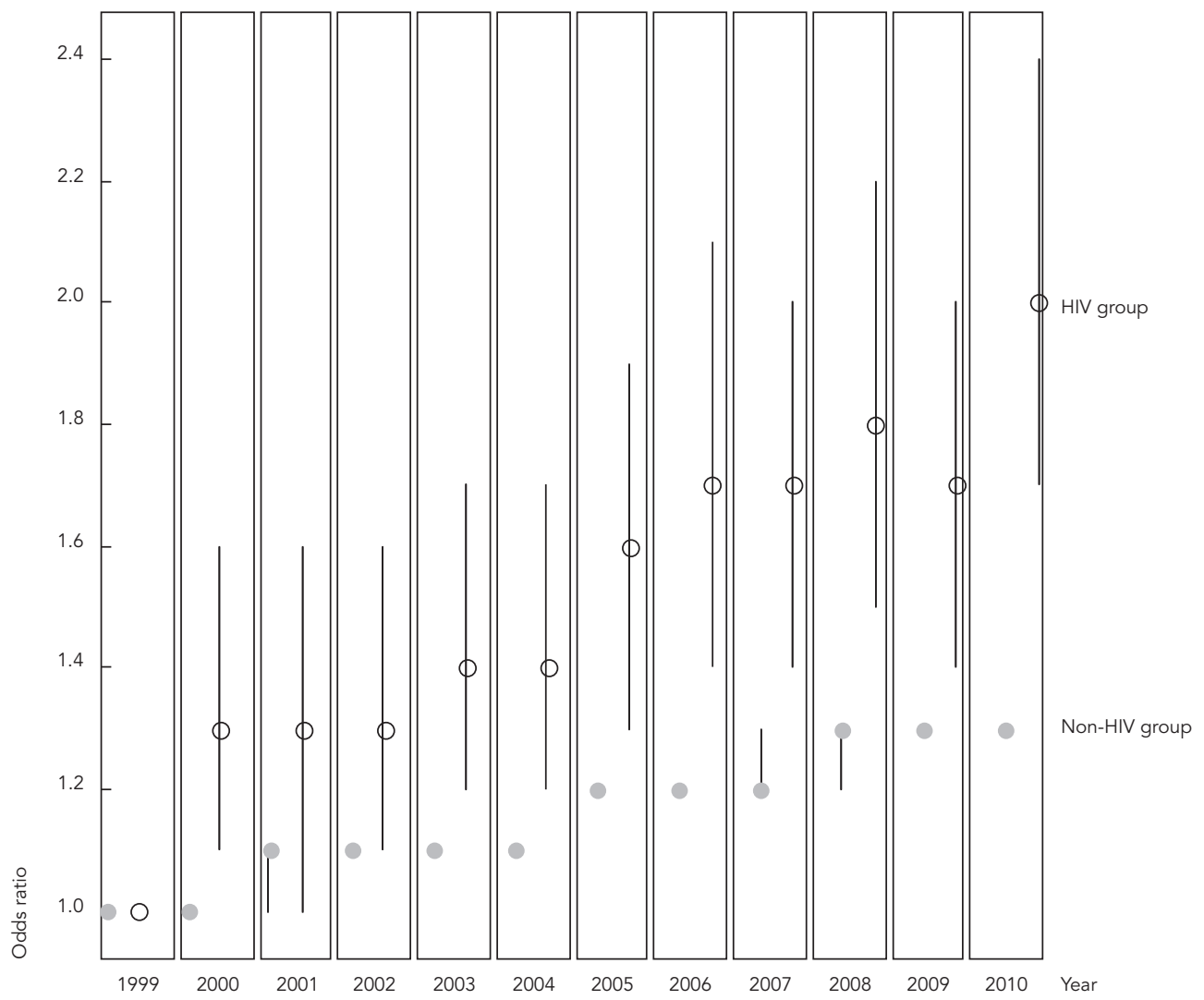

chronic inflammation characterizing HIV infection are associated with greater risk of cardiovascular diseases in persons with HIV/AIDS 19,20 Some studies have shown greater risk of cardiovascular events in persons with HIV/AIDS and on HAART as compared to those without treatment 21,22. Among the antiretroviral drugs, the protease inhibitors 23 , lopinavir-ritonavir or indinavir 24 , and regimens containing abacavir or didanosine 25 show greater risk of cardiovascular diseases.

In view of the population aging of persons with HIV/AIDS, prolonged use of HAART, long contact with the virus, and high prevalence of risk factors for cardiovascular diseases in this population, several authors have discussed specific approaches to screen and diagnose cardiovascular diseases in persons with HIV/AIDS 26. However, more research is needed to better elucidate the relationship between HIV, HAART, and cardio- vascular diseases. The current recommendations for avoiding cardiovascular diseases in persons with HIV/AIDS are still similar to the recommendations for the general population. Strategies to decrease the risk of cardiovascular diseases in persons with HIV/AIDS should be incorporated into the primary care for these patients.

The trends in mortality curves from nonAIDS-related malignant neoplasms also differ between the two groups; as demonstrated 13,16, the increase is greater in the HIV group. Although the incidence of AIDS-related neoplasms has decreased since the introduction of HAART, it is known that non-AIDS-related malignant neoplasms are currently important causes of mortality in persons with HIV/AIDS in the developed countries 13,14 . The increase in the proportion of deaths from non-AIDS-defining malignant neoplasms in persons with HIV/AIDS can be attributed to: (i) aging of the HIV-infected population; 
(ii) presence of risk factors such as smoking and alcohol abuse, which present high prevalence among persons with HIV/AIDS 27; (iii) immunosuppression caused by HIV 28, (iv) co-infection with oncogenic viruses ${ }^{29}$; and (v) the probable oncogenic effect of HAART 30 . In agreement with other studies, 30,31, malignant neoplasms of the lungs and hepatocellular carcinoma were more frequent among the HIV group. Preventive measures against these neoplasms could include, for example, cessation of risk behaviors such as alcoholism and smoking, improved screening and diagnosis of neoplasms in persons with HIV/AIDS, screening for infection with hepatitis B and hepatitis $C$ virus, and vaccination of the adult population against hepatitis $\mathrm{B}$.

Diseases of the genitourinary system also show a higher proportional increase in the HIV group when compared to the non-HIV group, corroborating findings by other authors 32,33 . HIV-related nephropathies can be caused by HIV itself or by the adverse effect of nephrotoxic drugs, leading to altered renal function due to the induction of metabolic vasculopathy and direct renal injury ${ }^{3}$. This would explain the significantly greater increase in diseases of the genitourinary system in the HIV group. Among these diseases, renal failure (codes N17 to N19 of ICD-10) play an important role in the increased mortality in the HIV group, since when removing this disease from the analysis of diseases of the genitourinary system, the difference between the curves in the two groups disappears.

This study demonstrated that listing of diabetes mellitus on death certificates has increased over time in the HIV and non-HIV groups. The increase in mortality from diabetes mellitus in the two groups agrees with studies that show an increase in incidence of diabetes mellitus, in the proportion of hospital admission for diabetes mellitus, and in the proportion of deaths from diabetes mellitus in the Brazilian population 34. Since persons with HIV/AIDS are exposed to the same risk factors as the general population, plus additional metabolic factors specific to HIV and HAART that increase the risk of developing diabetes mellitus, it was expected that mortality from diabetes would increase at a significantly higher rate in the HIV group as compared to the non-HIV group. However, the current study showed no difference between these mortality curves. A possible explanation is that persons with diabetes mellitus usually die from chronic complications of the disease such as cardiovascular diseases and renal failure, which end up being recorded as the causes of these deaths. And since listing of cardiovascular diseases and renal failure on death certificates increased more in the HIV group compared to the non-HIV group, diabetes mellitus may also be increasing at a higher rate in the HIV group compared to the non-HIV group.

The study presents some limitations. First, there are inherent obstacles to the use of data from death certificates, since completing the certificates depends exclusively on the assessment of the attesting physician, which may vary according to school and region, or even according to the understanding of which causes should be listed 35 . In addition, since the study only analyzed vital statistics, it was not possible to assess factors associated with greater mortality risk such as HAART, date of diagnosis, CD4+ count, and presence of other risk factors such as injection drug use, smoking, and alcoholism.

Another limitation relates to the definition of HIV group used in this study. The HIV group only included persons whose DC mentioned HIV/ AIDS. However, a study in Rio de Janeiro estimated that some $30 \%$ of deaths in patients known to be HIV-positive failed to mention HIV/AIDS anywhere on the DC 36 , suggesting that the HIV group is underestimated in this study. However, as mentioned by Pacheco et al. ${ }^{4}$ in their article's discussion, the mortality rate for deaths that mentioned HIV/AIDS on the DC remained stable over time, in agreement with the mortality data on AIDS in Brazil. Thus, since the study's analysis focused on year of death, it is believed that the underestimation of deaths in the HIV group does not invalidate the results.

In conclusion, this study's results point to a greater increase in mortality from cardiovascular diseases, diseases of the genitourinary system, and non-AIDS-related malignant neoplasms among persons with HIV/AIDS when compared to non-HIV-infected persons. These results suggest that long contact with HIV and HAART play an important role in the occurrence of these diseases. Thus, it is indispensable that the clinical management of these patients includes the prevention, diagnosis, and treatment of such diseases. As other authors have recommended, the results presented here reinforce the need to integrate the care for persons with HIV/AIDS with other public health programs 4. 


\section{Resumen}

Este estudio tiene como objetivo analizar la tendencia en la mención de las causas de muerte no relacionadas con el VIH/ SIDA, en los certificados de defunción de los adultos que vivían con el VIH/SIDA en Brasil. Se estudiaron con detenimiento los datos de las muertes de los adultos brasileños entre 1999 y 2010, además, se utilizaron las odds ratios estandarizadas de mortalidad para comparar las causas de muerte entre las personas que vivían con el VIH/SIDA y las personas que no vivían con la enfermedad. De 1999 a 2010, se produjeron 6.120.670 muertes de adultos en Brasil. En un 2,2\% del total de muertes en adultos, el VIH/SIDA figuraba mencionado en el certificado de defunción. Las causas no asociadas al VIH/SIDA, más específicamente, las enfermedades cardiovasculares, las enfermedades genitourinarias y neoplasias malignas, presentan un aumento de mayor intensidad en la frecuencia respecto a las que se enumeran como causas de muerte para quienes también vivían con el VIH.

Síndrome de Inmunodeficiencia Adquirida; $V I H$ Causas de Muerte; Certificado de Defunción

\section{Contributors}

E. Fazito contributed to the study conceptualization and design, data acquisition, data analysis and interpretation, and writing, revision, and authorization of the manuscript for publication. A. M. N. Vasconcelos collaborated in the study conceptualization and design, data analysis and interpretation, and writing and authorization of the manuscript for publication. M. G. Pereira participated in the study conceptualization and design, data and interpretation, and revision for publication. D. F. Rezende in the study conceptualization and design, data interpretation, and final revision for publication.

\section{References}

1. Ministério da Saúde. Boletim Epidemiológico AIDS e DST 2012; Ano VIII, n. 1.

2. Pereira CCA, Machado CJ, Rodrigues RN. Perfis de causas múltiplas de morte relacionadas ao HIV/ AIDS nos municípios de São Paulo e Santos, Brasil, 2001. Cad Saúde Pública 2007; 23:645-55.

3. Programa Nacional de DST e Aids, Secretaria de Vigilância em Saúde, Ministério da Saúde. Recomendações para terapia antirretroviral em adultos infectados pelo HIV. 7ạ Ed. Brasília: Ministério da Saúde; 2008. (Série Manuais, 2).

4. Pacheco AG, Tuboi SH, Faulhaber JC, Harrison LH Schechter M. Increase in non-AIDS related conditions as causes of death among HIV-infected individuals in the HAART era in Brazil. PLoS ONE 2008; 3:e1531.5.
5. Programa Nacional de DST/AIDS, Secretaria de Vi gilância em Saúde, Ministério da Saúde. Critérios de definição de casos de AIDS em adultos e crian ças. Brasília: Ministério da Saúde, 2004. (Manuais, $60)$.

6. Miettinen OS. Standardization of risk ratios. Am J Epidemiol 1972; 96:383-8.

7. Wolfe F, Hassett AL, Walitt B, Michaud K. Mortality in fibromyalgia: a study of 8,186 patients over thirty-five years. Arthritis Care Res (Hoboken) 2011; 63:94-101.

8. Lee LJ, Chung CW, Ma YC, Wang GS, Chen PC, Hwang $\mathrm{YH}$, et al. Increased mortality odds ratio of male liver cancer in a community contaminated by chlorinated hydrocarbons in groundwater. Occup Environ Med 2003; 60:364-9 
9. Smith KR, Kliewer EV. Estimating standardized mortality odds ratios with national mortality followback data. Epidemiology 1995; 6:55-60.

10. Ramos Jr. AN, Matida LH, Hearst N, Heukelbach J. Mortality in Brazilian children with HIV/AIDS: the role of non-AIDS-related conditions after highly active antiretroviral therapy introduction. AIDS Patient Care STDS 2011; 25:713-8.

11. Mocroft A, Brettle R, Kirk O, Blaxhult A, Parkin JM, Antunes F, et al. Changes in the cause of death among HIV-positive subjects across Europe: results from the EuroSIDA study. AIDS 2002; 16:1663-71.

12. French AL, Gawel SH, Hershow R, Benning L, Hessol NA, Levine AM, et al. Trends in mortality and causes of death among women with HIV in the United States: a 10-year study. J Acquir Immune Defic Syndr 2009; 51:399-406.

13. Sackoff JE, Hanna DB, Pfeiffer MR, Torian LV. Causes of death among persons with AIDS in the era of highly active antiretroviral therapy: New York City. Ann Intern Med 2006; 145:397-406.

14. Crum NF, Riffenburgh RH, Wegner S, Agan BK, Tasker SA, Spooner KM, et al. Comparisons of causes of death and mortality rates among HIV infected persons: analysis of the pre-, early, and late HAART (highly active antiretroviral therapy) eras. J Acquir Immune Defic Syndr 2006; 41:194-200.

15. Palella Jr. FJ, Baker RK, Moorman AC, Chmiel JS, Wood KC, Brooks JT, et al. Mortality in the highly active antiretroviral therapy era: changing causes of death and disease in the HIV outpatient study. J Acquir Immune Defic Syndr 2006; 43:27-34.

16. Aldaz P, Moreno-Iribas C, Egüés N, Irisarri F, Floristan Y, Sola-Boneta J, et al. Mortality by causes in HIV-infected adults: comparison with the general population. BMC Public Health 2011; 11:300.

17. Cockerham L, Scherzer R, Zolopa A, Rimland D, Lewis CE, Bacchetti P, et al. Association of HIV infection, demographic and cardiovascular risk factors with all-cause mortality in the recent HAART era. J Acquir Immune Defic Syndr 2010; 53:102-6.

18. Reinsch N, Neuhaus K, Esser S, Potthoff A, Hower M, Mostardt S, et al. Are HIV patients undertreated? Cardiovascular risk factors in HIV: results of the HIV-HEART study. Eur J Prev Cardiol 2012; 19:267-74.

19. Friis-Møller N, Sabin CA, Weber R, d'Arminio Monforte A, El-Sadr WM, Reiss P, et al. Combination antiretroviral therapy and the risk of myocardial infarction. N Engl J Med 2003; 349:1993-2003.

20. Mary-Krause M, Cotte L, Simon A, Partisani M, Costagliola D; Clinical Epidemiology Group from the French Hospital Database. Increased risk of myocardial infarction with duration of protease inhibitor therapy in HIV-infected men. AIDS 2003; 17:2479-86.

21. Law M, Friis-Møller N, Weber R, Reiss P, Thiebaut $\mathrm{R}$, Kirk $\mathrm{O}$, et al. Modelling the 3-year risk of myocardial infarction among participants in the Data Collection on Adverse Events of Anti-HIV Drugs (DAD) study. HIV Med 2003; 4:1-10.

22. Glass TR, Ungsedhapand C, Wolbers M, Weber R, Vernazza PL, Rickenbach M, et al. Prevalence of risk factors for cardiovascular disease in HIVinfected patients over time: the Swiss HIV Cohort Study. HIV Med 2006; 7:404-10.
23. DAD Study Group; Friis-Møller N, Reiss P, Sabin CA, Weber R, Monforte AD. Class of antiretroviral drugs and the risk of myocardial infarction. N Engl J Med 2007; 356:1723-35.

24. Worm SW, Sabin C, Weber R, Reiss P, El-Sadr W, Dabis F, et al. Risk of myocardial infarction in patients with HIV infection exposed to specific individual antiretroviral drugs from the 3 major drug classes: the data collection on adverse events of anti-HIV drugs (D:A:D) Study. J Infect Dis 2010; 201:318-30.

25. D:A:D Study Group; Sabin CA, Worm SW, Weber R, Reiss P, El-Sadr W, et al. Use of nucleoside reverse transcriptase inhibitors and risk of myocardial infarction in HIV-infected patients enrolled in the D:A:D study: a multi-cohort collaboration. Lancet 2008; 371:1417-26.

26. Hsue PY, Squires K, Bolger AF, Capili B, Mensah GA, Temesgen Z, et al. Screening and assessment of coronary heart disease in HIV-infected patients. Circulation 2008; 118:41-7.

27. Savès $M$, Chêne $G$, Ducimetière $P$, Leport $C$, Le Moal G, Amouyel P, et al. Risk factors for coronary heart disease in patients treated for human immunodeficiency virus infection compared with the general population. Clin Infect Dis 2003; 37:292-8.

28. Vacher-Coponat H, Dussol B, Berland Y. Affections néoplasiques et transplantations d'organes. Rev Med Interne 1999; 20:992-1003.

29. Gastaut J, Collesto R, Poizot-Martin I. VIH/SIDA et cancers: les affections malignes aucours de l'infection par le VIH. Paris: Ellipses; 2001.

30. Monforte A, Abrams D, Pradier C, Weber R, Reiss P, Bonnet F, et al. HIV-induced immunodeficiency and mortality from AIDS-defining and non-AIDSdefining malignancies. AIDS 2008; 22:2143-53.

31. Shiels MS, Cole SR, Mehta SH, Kirk GD. Lung cancer incidence and mortality among HIV-infected and HIV-uninfected injection drug users. J Acquir Immune Defic Syndr 2010; 55:510-5.

32. Estrella MM, Parekh RS, Abraham A, Astor BC, Szczech LA, Anastos K, et al. The impact of kidney function at highly active antiretroviral therapy initiation on mortality in HIV-infected women. J Acquir Immune Defic Syndr 2010; 55:217-20.

33. Fischer MJ, Wyatt CM, Gordon K, Gibert CL, Brown ST, Rimland D, et al. Hepatitis $\mathrm{C}$ and the risk of kidney disease and mortality in veterans with HIV. J Acquir Immune Defic Syndr 2010; 53:222-6.

34. Sartorelli DS, Franco LJ. Tendências do diabetes mellitus no Brasil: o papel da transição nutricional. Cad Saúde Pública 2003; 19 Suppl 1:S29-36.

35. Ishitani LH, França E. Uso das causas múltiplas de morte em saúde pública. Inf Epidemiol SUS 2001; 10:163-75.

36. Pacheco AG, Saraceni V, Tuboi SH, Lauria LM, Moulton LH, Faulhaber JC, et al. Estimating the extent of underreporting of mortality among HIVinfected individuals in Rio de Janeiro, Brazil. AIDS Res Hum Retroviruses 2011; 27:25-8.

Submitted on 31/Aug/2012

Final version resubmitted on 21/Jan/2013

Approved on 06/Feb/2013 